\title{
Species-specific identification of adulteration in cooked mutton Rista (a Kashmiri Wazwan cuisine product) with beef and buffalo meat through multiplex polymerase chain reaction
}

\author{
M. Mansoor Bhat ${ }^{1}$, Mir Salahuddin ${ }^{1}$, Imtiyaz A. Mantoo ${ }^{1}$, Sheikh Adil ${ }^{2}$, Henna Jalal ${ }^{1}$ and M. Ashraf Pal ${ }^{1}$
}

\begin{abstract}
1. Division of Livestock Products Technology, Sher-e-Kashmir University of Agricultural Sciences \& Technology of Kashmir, Shuhama, Alusteng, Srinagar - 190 006, Jammu and Kashmir, India; 2. Division of Livestock Production and Management, Sher-e-Kashmir University of Agricultural Sciences \& Technology of Kashmir, Shuhama, Alusteng, Srinagar - 190 006, Jammu and Kashmir, India.

Corresponding author: M. Mansoor Bhat, e-mail: mohammadmansoor212@gmail.com, MS: salahm@rediffmail.com, IAM: imtiyazsr@gmail.com, SA: aadilsheikh5@gmail.com, $\mathrm{HJ}$ : drhennajalal@rediffmail.com, MAP: palashraf@gmail.com
\end{abstract}

Received: 16-08-2015, Revised: 13-01-2016, Accepted: 22-01-2016, Published online: 03-03-2016

doi: 10.14202/vetworld.2016.226-230 How to cite this article: Bhat MM, Salahuddin M, Mantoo IA, Adil S, Jalal H, Pal MA (2016) Species-specific identification of adulteration in cooked mutton Rista (a Kashmiri Wazwan cuisine product) with beef and buffalo meat through multiplex polymerase chain reaction, Veterinary World, 9(3): 226-230.

\begin{abstract}
Aim: Meat adulteration is a serious problem in the meat industry and needs to be tackled to ensure the authenticity of meat products and protect the consumers from being the victims. In view of such likely problem in indigenous meat products of Kashmiri cuisine (Wazwan), the present work was performed to study the detection of beef and buffalo meat in cooked mutton Rista by mitochondrial DNA (mtDNA) based multiplex polymerase chain reaction (PCR) method under laboratory conditions.

Materials and Methods: Three experimental trials were conducted wherein the products were prepared from pure mutton, beef and buffalo meat, and their admixtures in the ratios of 60:20:20, 80:10:10, 90:05:05 and 98:01:01, respectively.

Results: The primers used in the study amplified the cyt $b$ gene fragments of sizes $124 \mathrm{bp}, 472 \mathrm{bp}$ and 585 bp for buffalo, cattle and sheep, respectively. It was possible to detect cattle and buffalo meat at the level of $1 \%$ in the mixed meat cooked Rista. The multiplex PCR successfully amplified $c y t b$ gene fragments of mtDNA of the target species and thus produced characteristic band pattern for each species. The band intensities of cattle and buffalo in the mixed meat Rista progressively decreased corresponding to their decreasing level from $20 \%$ to $1 \%$. Processing, cooking (moist heating) and non-meat formulation ingredients had no effect on detection of meat species adulteration.
\end{abstract}

Conclusion: The multiplex PCR procedure standardized and developed in this study is simple, efficient, sensitive, reliable and highly specific for detecting falsification of cooked mutton product with beef and buffalo meat up to $1 \%$ level.

Keywords: meat adulteration, meat species identification, mitochondrial DNA, multiplex polymerase chain reaction.

\section{Introduction}

The first case of fraudulent substitution was recorded in $13^{\text {th }}$ century A.D. at Florence in Italy [1], and this fraudulent adulteration of costly meat with cheap meat is a common practice observed throughout the world. The ability to detect less desirable or objectionable species in meat products is important not only for economic, health, religious, and ethical reasons; but also to ensure fair trade and compliance with legislation [2].

Meat species identification using enzymelinked immunosorbent assays [3] and protein profiles [4] have been used but in recent years, molecular authentication methodologies based on polymerase chain reaction (PCR) amplification have been developed and successfully applied for species

Copyright: Bhat, et al. Open Access. This article is distributed under the terms of the Creative Commons Attribution 4.0 International License (http://creativecommons.org/licenses/by/4.0/), which permits unrestricted use, distribution, and reproduction in any medium, provided you give appropriate credit to the original author(s) and the source, provide a link to the Creative Commons license, and indicate if changes were made. The Creative Commons Public Domain Dedication waiver (http://creativecommons.org/ publicdomain/zero/1.0/) applies to the data made available in this article, unless otherwise stated. authentication in meat products [5]. The advantages of DNA-based analysis are manifold. First is the ubiquity of DNA from all cell type of an individual contains identical genetic information independent of the origin of the samples. Second, the information content of DNA is a more abundant compared to proteins due to the degeneracy of the genetic codes. Third, DNA is a rather stable molecule that renders the extraction and analysis of DNA from many different types of samples feasible [6]. PCR analysis of species-specific mitochondrial DNA (mtDNA) sequences is the most common method currently used for identification of meat species in food [7-12] and animal feedstuffs [13-15]. Of late, the PCR assays have been employed for the identification of species origin of meat and meat products targeting genomic and mtDNA [16-19]. The detection of species origin of meat employing species-specific primer pairs was employed for authentication of mammalian and poultry species $[17,20]$. Species-specific PCR assay was developed for quick and authentic identification of chicken, beef and buffalo meat, even in heat processed admixed meat products containing the non-targeted species [21]. 
Wazwan is a multi-course meal in Kashmiri cuisine that is being served at various restaurants and marriage ceremonies with Rista as a famous course prepared in red chilli powder and other spices in a very special manner. The present study was thus performed to study the species-specific detection of low-cost beef and buffalo meat adulteration in cooked mutton Rista emulsion using multiplex PCR of $c y t b$ gene fragments under laboratory conditions.

\section{Materials and Methods \\ Ethical approval}

Ethical approval was not necessary as all meat samples were procured from the open market.

\section{Raw materials}

Hot boned mutton, beef and buffalo meat from leg portion of the respective dressed carcass were procured from the open market, packaged in properly labeled low density polythene (LDPE) bags and transported to the Division of Livestock Products Technology, Shere-Kashmir University of Agricultural Sciences and Technology of Kashmir (SKUAST-K) for preparation of the product.

\section{Preparation of Rista}

The product was prepared according to the standardized processing schedule (Table-1) and recipe of Samoon (1988) with slight modifications. The basic formulation for Rista, prepared under various controls, viz. mutton $\left(\mathrm{C}_{\mathrm{M}}\right)$, beef $\left(\mathrm{C}_{\mathrm{B}}\right)$ and carabeef $\left(\mathrm{C}_{\mathrm{C}}\right)$ as well as treatments, viz. the admixture of three meats, respectively, in percentages of 60:20:20 $\left(\mathrm{T}_{1}\right), 80: 10: 10$

Table-1: Standardized recipe for Rista.

\begin{tabular}{lc}
\hline Name of ingredients & Quantity (g) \\
\hline Raw meatballs & 500 \\
Water & 1000 \\
Hydrogenated vegetable oil & 62.50 \\
Turmeric powder & 12.50 \\
Red chili extract & 125 \\
Large cardamom & 1.25 \\
Small cardamom & 0.50 \\
Cinnamon & 1.75 \\
Cloves & 0.25 \\
Dried ginger powder & 2.00 \\
Garlic paste & 4.00 \\
Fried leek paste & 25 \\
Common salt & 5.00 \\
\hline
\end{tabular}

$\left(\mathrm{T}_{2}\right)$, 90:5:5 $\left(\mathrm{T}_{3}\right)$ and 98:1:1 $\left(\mathrm{T}_{4}\right)$, is presented in Table-2. Further, the standardized recipe is presented in Table-2.

\section{Rista processing and sampling}

The cooked form of the product of mutton, beef and buffalo meat were prepared according to the standardized processing schedule and recipe [22] with slight modifications. In accordance with the formulation (Table-2), weighed portions of minced meat and fat from each species were taken for the desired meat component for the treatments (admixtures) after thorough mixing. Random samples of cooked Rista of about $50 \mathrm{~g}$ each was drawn separately from the four respective types of Rista. The samples so obtained were packaged in properly labeled LDPE bags and frozen stored at $-20^{\circ} \mathrm{C}$.

\section{mtDNA extraction}

The chemicals utilized for mtDNA extraction from the test samples were lysis buffer, proteinase-K, TE buffer, phenol (tris saturated, $\mathrm{pH} 8.0$ ), 10\% sodium dodecyle sulfate (SDS), chloroform, isoamyl alcohol, isopropyl alcohol, ethanol, 3M sodium acetate $(\mathrm{pH}$ 5.5). The mtDNA from test samples was extracted as per the standard protocol described by Ausubel et al. [23] with some modifications. About $300 \mathrm{mg}$ aliquot of the frozen test sample was cut into small pieces with a sterile scalpel and transferred to autoclaved porcelain mortar. The sample pieces were ground thoroughly by pestle with additions of liquid nitrogen. The test sample homogenate was transferred into a sterile $15 \mathrm{ml}$ tube, and liquid nitrogen was allowed to evaporate. Lysis buffer - ST $(0.5 \mathrm{ml})$ was added to the tube along with $5 \mu 1$ proteinase $\mathrm{K}$ and $10 \%$ SDS $(100 \mu \mathrm{l})$ to make final concentration of the latter to $2 \%$. The homogenate was incubated for $12-16 \mathrm{~h}$ (overnight) at $55^{\circ} \mathrm{C}$. At the end of incubation, the lysate was transferred to an autoclaved $15 \mathrm{ml}$ centrifuge tube and equal volume $0.5 \mathrm{ml}$ of tris saturated phenol $(\mathrm{pH}-8.0)$ was added and mixed gently for $10 \mathrm{~min}$. The lysate was then centrifuged at $10,000 \mathrm{rpm}$ and $15^{\circ} \mathrm{C}$ for $10 \mathrm{~min}$. The supernatant was transferred to a $2 \mathrm{ml}$ centrifuge tube and half the volume of tris saturated phenol:chloroform:isoamyl alcohol $(25: 24: 1)$ was added and mixed gently for $10 \mathrm{~min}$. It was centrifuged at $10.000 \mathrm{rpm}$ and $15^{\circ} \mathrm{C}$

Table-2: Proportions of meat and fat used in the formulation for Rista.

\begin{tabular}{lccccccc}
\hline $\begin{array}{l}\text { Percent } \\
\text { ingredients }\end{array}$ & \multicolumn{7}{c}{ Controls and treatments } \\
\cline { 2 - 7 } & $\mathbf{C}_{\mathbf{S}}{ }^{*}$ & $\mathbf{C}_{\mathbf{C}}{ }^{*}$ & $\mathbf{C}_{\mathbf{B}}{ }^{*}$ & $\mathbf{T}_{\mathbf{1}}{ }^{*}$ & $\mathbf{T}_{\mathbf{2}}{ }^{*}$ & $\mathbf{T}_{\mathbf{3}}{ }^{*}$ & $\mathbf{T}_{\mathbf{4}}{ }^{*}$ \\
\hline Mutton & 80 & - & - & $48(60)$ & $64(80)$ & $72(90)$ & $78.40(98)$ \\
Beef & - & 80 & - & $16(20)$ & $8(10)$ & $4(5.0)$ & $0.80(1.0)$ \\
Buffalo meat & - & - & 80 & $16(20)$ & $8(10)$ & $4(5.0)$ & $0.80(1.0)$ \\
Mutton fat & 20 & - & - & $12(60)$ & $16(80)$ & $18(90)$ & $19.60(98)$ \\
Beef fat & - & 20 & - & $4(20)$ & $2(10)$ & $1(5.0)$ & $0.20(1.0)$ \\
Buffalo meat fat & - & - & 20 & $4(20)$ & $2(10)$ & $1(5.0)$ & $0.20(1.0)$ \\
Total & 100 & 100 & 100 & 100 & 100 & 100 & 100 \\
\hline
\end{tabular}

${ }^{*} \mathrm{C}_{\mathrm{S}}, \mathrm{C}_{\mathrm{C}}$ and $\mathrm{C}_{\mathrm{B}}$ indicates pure meat Rista of mutton, beef and buffalo meat, respectively. $* \mathrm{~T}_{1}, \mathrm{~T}_{2}, \mathrm{~T}_{3}$ and $\mathrm{T}_{4}$ indicates mixed meat Rista with mutton, beef and buffalo meat as 60:20:20, 80:10:10, 90:05:05 and 98:01:01, respectively 
for $10 \mathrm{~min}$. The supernatant was transferred into $2 \mathrm{ml}$ centrifuge tube and equal volume of chloroform:isoamylalcohol (24:1) was added and mixed gently for $10 \mathrm{~min}$ and centrifuged at $10,000 \mathrm{rpm}$ and $15^{\circ} \mathrm{C}$ for $10 \mathrm{~min}$. The supernatant was collected into a $2 \mathrm{ml}$ centrifuge tube followed by the addition of $1 / 10^{\text {th }}$ volume of $3 \mathrm{M}$ sodium acetate $(\mathrm{pH} 5.5)$ and equal volumes of isopropyl alcohol. The tubes were slowly swirled to precipitate the DNA which was then washed thrice with $70 \%$ ethanol and air dried and then dissolved in $200 \mu \mathrm{l}$ volume autoclaved triple distilled water using properly marked $2 \mathrm{ml}$ tubes. The DNA samples (stock solution) were stored at $-20^{\circ} \mathrm{C}$ until further use. Quality, purity, and concentration of the extracted DNAs were checked by agarose gel electrophoresis and spectrophotometry.

\section{Primers for PCR}

Various primers used in the present study were as per Zarringhabaie et al. [24] and are listed in Table-3. The primers were procured from M/s RFCL Ltd., New Delhi and were supplied in freeze-dried form and were stored at $-20^{\circ} \mathrm{C}$ until their usage.

\section{PCR analysis}

The multiplex PCR was carried out in a thermocycler using $0.2 \mathrm{ml}$ thin wall PCR tubes. The $25 \mu \mathrm{l}$ PCR reaction volume comprised 1.6 $\mu \mathrm{l}$ $\mathrm{MgCl}_{2}(1.5 \mathrm{mM}), 0.5 \mu \mathrm{M}$ dNTP $(0.2 \mathrm{mM}), 4.5 \mu \mathrm{l}$ of common reverse primer and $1 \mu \mathrm{l}$ of each forward primer of sheep, cattle and buffalo $(0.015 \mathrm{mM}), 2 \mu \mathrm{l}$ of template DNA (50 ng), $2.5 \mu 1$ of $\times 10$ PCR buffer, $0.06 \mu 1$ Taq DNA polymerase (0.3 units) and remaining volumes $(10.84 \mu \mathrm{l})$ of autoclaved triple distilled water. The optimized PCR protocol comprised initial denaturation for $3 \mathrm{~min}$ at $94^{\circ} \mathrm{C}$, followed by 34 cycles of denaturation for $30 \mathrm{~s}$ at $94^{\circ} \mathrm{C}$, annealing at $60^{\circ} \mathrm{C}$ for $45 \mathrm{~s}$, extension at $72^{\circ} \mathrm{C}$ for $45 \mathrm{~s}$ and a final extension at $72^{\circ} \mathrm{C}$ for $10 \mathrm{~min}$. The PCR products were electrophoresed at $85 \mathrm{~V}$ for $2 \mathrm{~h}$ in $2 \%$ agarose gels after the wells were charged with $5 \mu \mathrm{l}$ of DNA preparations mixed with $1 \mu \mathrm{l}$ of $6 \mathrm{X}$ gel loading buffer dye and viewed under ultraviolet transilluminator gel documentation after staining with ethidium bromide. The sizes of PCR products were determined in relation to a 100 bp DNA ladder.

\section{Results}

The multiplex PCR profile of cooked pure and mixed meat Rista is present in Figure-1. The multiplex PCR amplified fragments exhibited the expected

Table-3: Primers used in multiplex PCR.

\begin{tabular}{lllc}
\hline Name & $\begin{array}{l}\text { Primer } \\
\text { type }\end{array}$ & Sequences $\left(5^{\prime}-\mathbf{3}^{\prime}\right)$ & $\begin{array}{c}\text { Size } \\
\text { (bp) }\end{array}$ \\
\hline Common & Reverse & TGTCCTCCAATTCATGTGAGTGT & - \\
Buffalo & Forward & TCCTCATTCTCATGCCCCTG & 124 \\
Cattle & Forward & TCCTTCCATTATCATCATAGCAA & 472 \\
Sheep & Forward & TACCAACCTCCTTCAGCAATT & 585 \\
\hline
\end{tabular}

$\mathrm{PCR}=$ Polymerase chain reaction species-specific band patterns. The amplified bands of $c y t b$ gene fragments were of the size of $124 \mathrm{bp}$, $472 \mathrm{bp}$ and $585 \mathrm{bp}$ for buffalo, cattle and sheep, respectively. For each mixed meat cooked Rista sample, three bands are present representing the meats of three species (sheep, cattle and buffalo) in the mixed meat of cooked Rista. In the case of pure meat Rista of mutton, beef and buffalo meat, only one band of the respective species is observed. It was possible to trace beef and buffalo meat in the cooked mutton Rista up to a level as low as $1 \%$. In pure meat samples, band intensities where of similar intensity. In mixed meat samples, the band intensities for the cattle and buffalo cyt $b$ gene fragments showed a progressive decrease with the decrease of their proportion from $20 \%$ to $1 \%$ in the cooked mutton Rista. The overall band intensities for sheep, cattle and buffalo $c y t b$ gene fragments were lower due to DNA degradation during cooking. The multiplex PCRs for cooked Rista were repeated 3 times with $100 \%$ reproducibility. Based on above observations, a highly sensitive method for detection of mixed meats in cooked mutton Rista by multiplex PCR stands standardized.

\section{Discussion}

The adulteration of meat species is a worldwide problem, which infringed food labeling laws, constitutes economic fraud, and raises ethical, religious and food safety concern [25]. Hence, detection of meat species by fast and accurate methods should routinely be carried out for the quality control as well as a public task to secure the food safety all over the world [26]. The speciation of cooked meat is difficult since the heat treatment during cooking causes extensive changes within the meat tissue [27]. In spite of these changes, short nucleic acid sequences are able to survive cooking processes which can be employed for the meat speciation purposes [28]. Hence, from the past two decades, significant efforts have been invested in the development of DNA-based meat speciation techniques. Nucleic acid-based analysis had widely used in many fields, and become more and more popular for differentiation and identification of feed or food

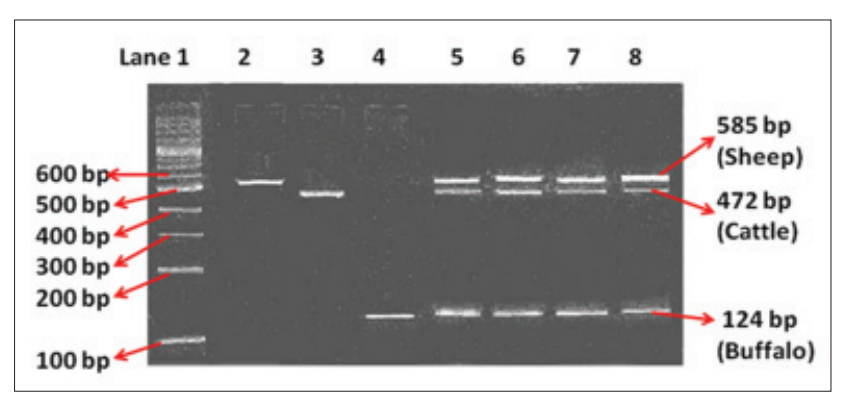

Figure-1: Species-specific multiplex polymerase chain reaction profile of cyt $b$ gene fragments of sheep, cattle and buffalo from cooked Rista. Lane 1: DNA ladder, Lane 2: Pure mutton, Lane 3: Pure beef, Lane 4: Pure buffalo meat, Lane 5-8: Mixed meat (mutton:beef:buffalo meat in the ratio of $60: 20: 20,80: 10: 10,90: 05: 05$ and 98:01:01, respectively). 
adulterants [13]. The most recently DNA-based PCR assays are widely employed for differentiation and identification of species origin of meat and meat products [29-33], due to high heat stability and highly conserved nature of DNA [16], increases the probability of positive results even in highly fragmented DNA in highly processed meat products [34]. Ballin, 2010 [35] also has reported that while the presence and characteristics of proteins depend on the tissue type being analyzed, DNA exists and is identical in almost all cells, and the unique variability and diversity afforded by the genetic code permits the discrimination of even closely-related species. Detection method based on mtDNA can improve the sensitivity further because of the presence of thousands of copies of mtDNA per cell against just a few sets of genomic DNA. The mtDNA are easier to be extracted as they are located in the cytoplasm [6]. Genes to be targeted for amplification can be $12 \mathrm{~S}, 16 \mathrm{~S}$ and $18 \mathrm{~S}$ rRNA, actin, cytochrome $b$, cytochrome oxidase-II, nicotinamide adenine dinucleotide dehydrogenase $5 / 6$ and $\mathrm{mtD}-\mathrm{loop}[36,26]$. The variation of mitochondrial $c y t b$ gene has been a rich source of phylogenetic inference in a wide range of animal species. The chances of mtDNA degradation under different meat processing conditions are lesser thus making it ideal for processed meat species identification [10]. Further, a higher copy number of mtDNA ensures a sufficiently large quantity of PCR product even in the case of samples undergoing intense DNA fragmentation [37].

The lowest detection level in the study was up to $1 \%$. Detection of meat speciation at similar levels of addition in mixed meats has been reported by Rodriguez et al. [38]. Furthermore, there were progressive decreases of the levels of beef and buffalo meat in the mixed meat cooked product samples and, therefore, the concentration of beef and buffalo meat mtDNA (in the extracted mtDNA) also showed progressive decrease with the reduction in the level of the two mixed meats from $20 \%$ to $1 \%$. As the band intensities and quality of mtDNA are correlated, therefore, the band intensities of beef and buffalo meat amplified DNA also showed a progressive decrease with the reduction of levels of these meats. These results on cooked Rista were in general conformity with the findings of Matsunaga et al. [8], Jain [39] and Sakalar and Abasiyanik [40]. The band intensities of beef and buffalo meat cyt $b$ gene fragments in cooked Rista were lower due to DNA fragmentation during cooking. The heat treatment affects the quality of DNA has also been reported by Martinez and Man [41] and Hird et al. [42].

\section{Conclusion}

The results of the present study clearly indicated that processing, the addition of cooking ingredients and cooking by traditional Kashmiri methods had no effect on detection of species of meat in the Rista. The present study supports the capability of mtDNA-based test to detect the meat falsification even at a lower level and is a herald to the fact that PCR is the method of choice for identifying meat species more efficiently and accurately even in highly processed Kashmiri cuisine products.

\section{Authors' Contributions}

This study is the part of M.V.Sc. thesis of the first author MMB, who carried out the research under the guidance of MS. IAM and HJ helped during the trial. SA and MAP helped in technical writing and revision of the article. All authors have read and approved the final version of the manuscript.

\section{Acknowledgments}

The authors are highly thankful to Directorate of Research, SKUAST-K for providing necessary funds to carry out the work.

\section{Competing Interests}

The authors declare that they have no competing interests.

\section{References}

1. Thornton, H. (1968) Textbook of Meat Inspection. $6^{\text {th }}$ ed. Tindall and Cassel, Bailliere, London.

2. Spink, J. and Moyer, D.C. (2011) Defining the public health threat of food fraud. J. Food Sci., 76: 157-163.

3. Chen, F.C. and Hsieh, Y.H. (2000) Detection of pork in heat-processed meat products by monoclonal antibody-based ELISA. J. AOAC Int., 83: 79-85.

4. Skarpeid, H.J., Kvaal, K. and Hildrum, K.I. (1998) Identification of animal species in ground meat mixtures by multivariate analysis of isoelectric focusing protein profiles. Electrophoresis, 19: 3103-3109.

5. Stamoulis, P., Stamatis, C., Saradou, T. and Mamuris, Z. (2010) Development and application of molecular markers for poultry meat identification in food chain. Food Control, 21: 1061-1065.

6. Cheng, Y.H., Wen, C.M., Ding, S.T., Kao, C.C. and Kuo, T.Y. (2003) Detecting meat-and-bone meal in ruminant's feeds by species-specific PCR. J. Anim. Feed Sci., 12: 851-860.

7. Meyer, R., Hofelein, C., Luthy, J. and Candrian, U. (1995) Polymerase chain reaction-restriction fragment length polymorphism analysis: A simple method for species identification in food. J. AOAC Int., 78: 1542-1551.

8. Matsunaga, T., Chikuni, T., Tanabe, R., Muroya, S., Shibata, K., Yamada, J. and Shimmura, Y. (1999) A quick and simple method for the identification of meat species and meat products by PCR assay. Meat Sci., 51(2): 143-148.

9. Montiel-Sosa, J.F., Ruiz-Pesini, E., Montoya, J., Roncales, P., Lopez-Perez, M.J. and Perez-Martos, M. (2000) Direct and highly species-specific detection of pork meat and fat in meat products by PCR amplification and mitochondrial DNA. J. Agric. Food Chem., 48: 2829-2832.

10. Partis, L., Croan, D., Guo, Z., Clark, R., Coldham, T. and Murby, J. (2000) Evaluation of a DNA fingerprinting method for determining the species origin of meats. Meat Sci., 54: 369-376.

11. Herman, B.L. (2001) Determination of the animal origin of raw food by species-specific PCR. J. Dairy Res., 68: 429-436.

12. Lahiff, S., Glennon, M., O’Brien, L., Lyng, J., Smith, T., Maher, M. and Shilton, N. (2001) Species-specific PCR for the identification of ovine, porcine and chicken species in meat and bone meal (MBM). Mol. Cell. Prob., 15: 27-35.

13. Tartaglia, M., Saulle, E., Pestalozza, S., Morelli, L., 
Antonucci, G. and Battaglia, P.A. (1998) Detection of bovine mitochondrial DNA in ruminant feeds: a molecular approach to test for the presence of bovine-derived materials. J. Food Prot., 61: 513-518.

14. Bellagamba, F., Moretti, V.M., Comincini, S. and Valfre, F. (2001) Identification of species in animal feedstuffs by polymerase chain reaction-restriction fragment length polymorphism analysis of mitochondrial DNA. J. Agric. Food Chem., 49: 3775-3781.

15. Krcmar, P. and Rencova, E. (2001) Identification of bovine-specific DNA in feedstuffs. J. Food Prot., 64: 117-119.

16. Girish, P.S., Anjaneyulu, A.S.R., Viswas, K.N., Shivakumar, B.M., Anand, M., Patel, M. and Sharma, B. (2005) Meat species identification by polymerase chain reaction-restriction fragment length polymorphism (PCRRFLP) of mitochondrial 12S rRNA gene. Meat Sci., 70: 107-112.

17. Arslan, A., Ilhak, I.O. and Calicioglu, M. (2006) Effect of method of cooking on identification of heat processed beef using polymerase chain reaction (PCR) technique. Meat Sci., 72: 326330 .

18. Mane, B.G., Mendiratta, S.K., Tiwari, A.K. and Bhilegaokar, K.N. (2012a) Development and evaluation of polymerase chain reaction assay for identification of buffalo meat. Food Anal. Methods, 5: 296-300.

19. Mane, B.G., Mendiratta, S.K. and Tiwari, A.K. (2012b) Beef specific polymerase chain reaction assay for authentication of meat and meat products. Food Control, 28: 246-249.

20. Meyer, R., Candrian, U. and Luthy, J. (1994) Detection of porkin heated meat products by the polymerase chain reaction. J. AOAC Int., 77: 617-622.

21. Mane, B.G., Mendiratta, S.K. and Tiwari, A.K. (2009) Polymerase chain reaction assay for identification of chicken in meat and meat products. Food Chem., 116: 806-810.

22. Samoon, A.H. (1988) Processing and Preservation of Ghoshtaba and Rista (Kashmiri meat products). M.V.Sc. Thesis, Deemed University, I.V.R.I., Izatnagar, U.P.

23. Ausubel, F.M., Brent, R., Kingston, R.E., Moore, D.D., Seidman, J.G., Smith, J. and Strehl, K. (1987) Preparation of genomic DNA from mammalian tissue. In: Current Protocols in Molecular Biology. Greene Publishing Associates/Wiley Inter science, New York, USA.

24. Zarringhabaie, G.E., Pirany, N. and Javanmard, A. (2011) Molecular traceability of the species origin of meats using Multiplex PCR. Afr. J. Biotechnol., 10(73): 15461-15465.

25. Abd El-Nasser, M., Labieb, H. and El-Aziz, D.M.A. (2010) Identification of meat species in some meat products in Assiut city. Ass. Univ. Bull. Environ. Res., 13(2): 1-12.

26. Unajak, S., Meesawat, P., Anyamaneeratch, K., Anuwareepong, D., Srikulnath, K. and Choowongkomon, K. (2011) Identification of species (meat and blood samples) using nested-PCR analysis of mitochondrial DNA. Afr. J. Biotechnol., 10(29): 5670-5676.

27. Gouli, Z., Mingguang, Z., Zhijiang, Z. and Hongsheng, O.L. (1999) Establishment of a polymerase chain reaction for the identification of beef. Meat Sci., 48: 233-236.
28. Ioja-Boldurai, O.M., Popescui, S., Bruznicani, S. and Hutu, I. (2011) Applicability of a multiplex PCR assay for the identification of animal species in feedstuffs. Bull. UASVM Anim. Sci. Biotechnol., 68: 1-2.

29. Mane, B.G., Mendiratta, S.K., Tiwari, A.K., Sharma, B.D., Bhilegaokar, K.N. and Anjaneyulu, A.S.R. (2011) Detection of pork in admixed meat and meat products by species specific PCR technique. Indian J. Anim. Sci., 81: 1178-1181.

30. Yusop, M.H.M., Mustafa, S., Yaakob, B., Man, C., Omar, A.R. and Mokhtar, N.F.K. (2012) Detection of raw pork targeting porcine specific mitochondrial cytochrome $b$ gene by molecular beacon probe real time polymerase chain reaction. Food Anal. Methods, 5: 422-429.

31. Haider, N., Nabulsi, I. and Al Safadi, B. (2012) Identification of meat species by PCR RFLP of the mitochondrial COI gene. Meat Sci., 90: 490-493.

32. Barakat, H., El-Garhy, H.A.S. and Moustafa, M.M.A. (2014) Detection of pork adulteration in processed meat by species-specific PCR-QIAxcel procedure based on D-loop and cytb genes. Appl. Microbiol. Biotechnol., 98(23): 9805-9816.

33. Doosti, A., Ghasemi, D.P. and Rahimi, E. (2014) Molecular assay to fraud identification of meat products. J. Food Sci. Technol., 51(1): 148-152.

34. Mane, B.G., Mendiratta, S.K. and Tiwari, A.K. (2013a) Pork specific polymerase chain reaction assay for authentication of meat and meat products. J. Meat Sci. Technol., 1(1): 24-30.

35. Ballin, N. (2010) Authentication of meat and meat products. Meat Sci., 86: 577-587.

36. Singh, P. and Neelam, S. (2011) Meat species specifications to ensure the quality of meat: A review. Inter. J. Meat Sci., 1: $15-26$.

37. Pascoal, A., Prado, M., Calo, P., Cepeda, A. and Barros, V.J. (2005) Detection of bovine DNA in raw and heat-processed foodstuffs, commercial foods and specific risk materials by a novel specific polymerase chain reaction method. Eur. Food Res. Technol., 220: 444-450.

38. Rodriguez, M.A., Garcia, T., Gonzalez, I., Asensio, L., Hernandez, P.E. and Martin, R. (2004) PCR identification of beef, sheep, goat and pork in raw and heat treated meat mixtures. J. Food Prot., 67(1): 172-177.

39. Jain, S. (2004) Use of cyt b gene variability in detecting meat species by multiplex PCR assay. M. V. Sc. Thesis, Anand Agricultural University, Anand, Gujarat.

40. Sakalar, E. and Abasiyanik, M.F. (2011) Qualitative analysis of meat and meat products by multiplex polymerase chain reaction technique. Afr. J. Biotechnol., 10(46): 9379-9386.

41. Martinez, I. and Man, Y. (1998) Species identification in meat products by RAPD analysis. Food Res. Int., 31(6): 459-466.

42. Hird, H., Chisholm, J., Sanchez, A., Hernandez, M., Goodier, R., Schneede, K., Boltz, C. and Popping, B. (2006) Effect of heat and pressure processing on DNA fragmentation and implications for the detection of meat using a real-time polymerase chain reaction. Food Addit. Contam., 23(7): 645-650.

\section{$* * * * * * * *$}

